\title{
ARTICle \\ 2014 John Dewey Lecture: \\ Does EVIDENCE MATTER?
}

\section{Diane Ravitch}

Thank you for inviting me to speak today.

John Dewey and I have had a long and occasionally contentious friendship. He taught me to think critically, and it is a habit I cannot get rid of. For that, I thank him. More than a dozen years ago, I gave a book talk at Teachers College, where I had been a professor for nearly twenty years. When I finished, Arthur Levine, who was then president of TC, got up and said incredulously, "You criticized John Dewey." And I responded, "John Dewey would have liked that. He taught me that we must keep thinking all the time."

I consider myself to be a disciple of Dewey's, even when I disagree with him. Of course, Lawrence Cremin was my mentor at Teachers College, and Larry too taught me that the essence of scholarship is to gather evidence carefully, to document what you write, and to keep thinking. It is in that spirit that I dedicate this lecture to my beloved mentor.

Over the past several years, I gained a certain notoriety for doing something that seems to be unprecedented. I changed my mind. When people ask why I changed my mind, I have two answers: First, I kept thinking. Second, I realized I was wrong. I did not have an overnight epiphany. I realized I was wrong. Period.

And because I came to that realization, I do whatever I can to adhere to Larry's advice and to try to shed light on how misguided our current education policies are, because they are the very embodiment of what I rejected: standards, testing, accountability, choice, competition.

Taken alone, I am not opposed to any one of those activities. I believe there is a role for standards as aspirational goals, not as mandates and not as a program that standardizes teaching or curriculum or children. A four-minute mile was for many years the standard for which all runners aimed; the record was broken in 1954 by Roger Bannister, and since then, many male runners have crossed that threshold. The fastest run by a female was four minutes and twelve seconds; someday a female athlete will reach the standard. The four-minute mile remains the standard for male middle-distance runners, but it would be madness to expect every runner to run four miles in a minute.

I am not opposed to testing. I think that the best tests are written by teachers, who know what they taught and who can get instant feedback and learn by seeing what their students did and did not understand. 


\section{Diane Ravitch}

I am not opposed to accountability, nor to choice, nor to competition.

But taken together, these concepts have become a battering ram that is ruining education, encouraging the privatization of public schools, demoralizing teachers, and undermining the teaching profession as such.

These are strong words, but I think they reflect the parameters of federal education policy today, which in turn influences education policy in every state and school district.

As I reflect on the evolution of federal policy, I recall the purpose of the Elementary and Secondary Education Act of 1965. It was passed specifically to address the needs of disadvantaged children. Its goal was to redistribute resources to the neediest schools and to protect the rights of the neediest students. Every seven years or so, the legislation was reauthorized, and its programs and strategies multiplied, but its central purpose remained the same: Equity.

In 2001, Congress reauthorized the ESEA and gave it a new name and a new purpose. Now it was called the No Child Left Behind law, and its purpose was to prod states and districts to raise test scores, so that no child would be left behind. NCLB changed the focus of federal education policy from seeking equity of resources to seeking equity of test scores. NCLB used the term "evidence-based" more than 100 times in its 1,000-plus pages, so this law is a good place to start to answer the question: "Does evidence matter?"

One can trace the origins of NCLB back to the famous 1983 report "A Nation at Risk," which prophesied doom for our nation because of a "rising tide of mediocrity." The report said that our nation had lost the auto industry to Japan because of our mediocre public schools. The commission pointed to Japan's impressive scores on international tests as proof that mediocre schools were causing us to lose jobs. Thirty years later, we can look back and say that the report was wrong. The loss of the auto industry to Japan was due not to the public schools, but to the shortsighted leaders of the American automobile industry, who failed to see that the public wanted fuel-efficient cars. Japan continues to have high international test scores, but its economy has stagnated for years, while our economy continues to be the largest in the world, driven by technological innovation and the high productivity of our workers, most of whom are the products of American public education.

"A Nation at Risk" was wrong, but it drove a frenzied search for solutions. The solution that political and business leaders settled on was standards and tests. Our kids were lazy, they thought, because they were not challenged enough in school. I will skip over the national education goals, proclaimed in 1990, where our governors agreed-among other things - that we would be first in the world in math and science by the year 2000. President George H. W. Bush called his education program "America 2000" and President Bill Clinton called his education program "Goals 2000."

One thing we know about politicians is that they believe in setting goals without having any strategy for getting there. The goal is supposed to be self-actualizing. 
So, when 2000 came and went without our having met any of the national goals set in 1990, it was time to set some new goals. Governor George W. Bush of Texas had the answer. He said there had been a "Texas miracle." Test every child every year from grades 3-8, publish the results, and miraculous things happen. The test scores go up every year, the achievement gap starts closing, and graduation rates go up. He said we must avoid "the soft bigotry of low expectations."

You can see where this is going. Set the bar high enough, and kids will jump higher. Require that every runner post a four-minute mile, and it will happen.

Researchers Walt Haney at Boston College and Stephen Klein at the RAND Corporation warned that there had been no Texas miracle, but no one listened. Certainly no one in Congress listened. They passed the NCLB legislation with large bipartisan majorities, and Senator Ted Kennedy stood by President George W. Bush's side proclaiming January 8, 2002, to be a historic day, "about the future of our nation and about the future of democracy, the future of liberty and the future of the United States in leading the free world."

NCLB mandated that every child from grades 3-8 must be tested annually, using a test of the state's choosing, and by 2014, every child must be proficient in reading and mathematics. Any school that was not making progress toward this target would be subject to a series of escalating sanctions, ending in the school being handed over to private management or to state control or turned into a charter school or closed.

Was there any evidence for the goals or for the sanctions? No. There is no nation in the world where 100 percent of the children are proficient in reading and math. There was not a shred of evidence in 2002 that a school would improve if it were handed over to state management, taken over by the state, turned into a charter school, or closed. But evidence didn't matter.

Seven years later, when a new administration took office, NCLB was already a tainted brand. Congress doesn't have the will or capacity to change it, doesn't have a goal better or bigger than 100 percent proficiency, so they left it on the books, where it is still the law of the land. Educators were disgusted with NCLB, believing that it overemphasized testing and resenting that they were forced to eliminate the arts and recess, to lay off arts teachers and school nurses, to make more time for testing and test prep. But no one listened to them. They were making excuses.

At first, the election of Barack Obama offered hope for genuine change because his educational advisor during the campaign was Linda Darling-Hammond, one of the most respected scholars in education. She was committed not only to meticulous research but to equity. It seemed that NCLB would soon be consigned to the ash heap of history, where it belonged.

But President Obama selected his friend Arne Duncan to be secretary of education. Duncan had headed the Chicago public schools, where he cultivated close relationships with the Gates Foundation and the Broad Foundation. Soon 
he brought forth his signature program called Race to the Top, and it proved to be even more pernicious than No Child Left Behind. He designed it with the help of allies from the Gates Foundation and the Broad Foundation, and he hired the CEO of the NewSchools Venture Fund to run it. The NewSchools Venture Fund is the epicenter of the privatization movement in education, dedicated to creating charters and charter chains to compete with public schools. NSVF believes that the private sector is not only more innovative but more boldly disruptive than the public sector. Its current CEO, Ted Mitchell, was recently named by Duncan to be undersecretary of education, the second most powerful job in the department.

Race to the Top enjoyed an unprecedented amount of discretionary funding. After the economic collapse of 2008, Congress passed a huge economic recovery plan, and the U.S. Department of Education received $\$ 5$ billion to spend as it wished. Duncan used this money to create a competition among the states. To be eligible for the Race, states had to agree to lift the cap on privately managed charter schools, to adopt "college and career ready standards" (understood to be the Common Core standards, which the Gates Foundation had generously funded), to evaluate teachers to a significant degree by the test scores of their students, and to take drastic action to change low-performing schools, such as firing the principal and half or all of the staff or closing the school.

Was there any evidence in 2009 that charter schools performed better than public schools? No. Was there any evidence that the Common Core standards-not yet finished, reviewed, or evaluated-would improve test scores or improve education? No. Was there any evidence that schools would improve if half or all of their staff was fired? No. Was there any evidence that test scores could be appropriately used to evaluate teacher quality? No.

Despite the lack of evidence, there was $\$ 4.3$ billion on the table, and states began changing their laws so they could be eligible to compete for the big payout. Some forty-five states endorsed the Common Core standards, in some cases, sight unseen. An equal number enacted laws to evaluate teachers by the rise or fall of the test scores of their students. Remember, the states were all strapped for cash, and they would do anything to get a share of the prize. Massachusetts even agreed to abandon its own highly praised standards and testing program and adopt the untested Common Core so as to be eligible.

Race to the Top looked suspiciously like No Child Left Behind. Like NCLB, the focus was on raising test scores, not equity. Gone was chitchat about equality of opportunity; the new goal was winning, beating the competition, getting to the top. The top, I suppose, was the top of the international league tables. Like NCLB, Race to the Top approached school reform as an exercise in finding the right mix of carrots and sticks. States and schools that wanted money had to do what Duncan wanted, even though there was no evidence for any of his preferred policies. 
Like NCLB, Race to the Top is based on the belief that teachers must be motivated by the promise of a bonus or the fear of firing. The National Research Council published a major report in 2011 saying that test-based incentives-of the kind promoted by No Child Left Behind and Race to the Top-are ineffective. It represents the behaviorist thinking of the early twentieth century, the social efficiency best epitomized by Frederick Winslow Taylor. Cognitive psychologists today recognize that if you pay people to do what they want to do, they do it less well; they recognize that the greatest motivation is idealism, professional autonomy, and a sense of purpose. People become teachers because they want to make a difference in the lives of children, not because they want a bonus.

Yet, the policymakers continue to look for the right combination of rewards and threats, for bonuses and threats for teachers as well as children, and they are surprised when this approach fails again and again.

Because of NCLB and RTTT, the standardized testing industry has assumed a position of power in American society that it had never known before. Not only do the reputation and career of every teacher and principal hinge on student test scores, but the very survival of schools that were once considered the heart of their community is now tied to their test scores. The scores became sacred totems of our society, the measure that defines success or failure for individuals and institutions.

Did anyone at the Department of Education give thought to the consequences of making scores on standardized tests so important? Apparently not. Some states, like Illinois and New York, played games with the passing mark on their state exams, to make it appear that they were making great progress. Some superintendents got into legal trouble for tolerating or encouraging cheating, like those in Atlanta and El Paso.

But little thought was given to the stratification inherent in the use of standardized testing. Instead of aiming to provide all children with a full education, instead of doing their best to develop the character, talents, and abilities of every child to the fullest, our nation's public schools became obsessed with standardized testing. The results were predictable, as they are on every standardized test. The students from the most affluent homes cluster in the top half, and the students who are most disadvantaged cluster in the bottom half. Standardized testing benefits the haves and stigmatizes the have-nots, those who have not equality of educational or economic opportunity. Standardized testing, as used today, becomes an instrument to confer privilege on those who are already privileged.

Legislators assume that the way to make kids smarter is to make tests harder. This is NCLB all over again. Raise the bar and children will jump higher. Making the tests harder means more money for test prep, more money for data coaches, more money for consultants, and less time for instruction. Some states have passed laws saying that children can't leave third grade unless they can read at third-grade 
level. What is the evidence for this law? There is none. Children will be discouraged and give up, not try harder.

Policymakers treat standardized tests as infallible instruments, as if they were as reliable as a thermometer or a yardstick. They are wrong. They do not acknowledge that there is random error, statistical error, sampling error, human error, and many other kinds of error. They do not realize that sometimes test questions are poorly written, and some questions may have more than one right answer or no right answer at all. Standardized tests do not improve achievement, they measure it. They do not reduce achievement gaps, they measure them. They accurately reflect family income and education. Some rich kids do poorly, and some poor kids get high scores; but they are the exception, not the rule.

Thus, if the Department of Education were interested in promoting equity, it would have used that $\$ 5$ billion to send resources to the schools that needed them most, or it would have had a competition for districts that develop the best plan to increase racial integration. Instead, it created a competition that made test scores even more important than they were under NCLB. The meager results would have been predictable if anyone at the Department of Education cared about evidence.

The schools likeliest to be closed were in low-income communities, enrolling disproportionate numbers of students with disabilities and students who were English language learners. The teachers likeliest to be fired were those who taught the children with the highest needs.

That was predictable too.

Race to the Top has been a boon to the charter industry.

There are now over 6,000 charter schools, and on average, they get the same or worse results than public schools. Some get very high scores, but those that do tend to have high attrition rates, high teacher turnover, and small proportions of students with disabilities and ELLs. Somehow the media, which loves stories about high-flying charters, never bothers to look beyond the test scores. Why let evidence get in the way of a good story?

Every so often, President Obama or Secretary Duncan points out a school that has achieved a miracle; they have pointed proudly to turnaround schools, where every member of the old staff was fired and replaced. Within two or three years, they say, 100 percent of its students graduate and go to college. It is a miracle! On closer examination, none of these so-called miracle schools survives close scrutiny. Typically, their success depends on their ability to quietly remove half their entering students, winnowing out those with low scores, counseling out those with disabilities, and spending long hours prepping for the state tests. The media doesn't have the know-how or interest in fact-checking. In 2011, when Governor Scott Walker of Wisconsin was at war with the state teachers' union, when teachers and their allies encircled the state capitol to protest the governor's plan to take away their collective bargaining rights: Where were President Obama and Secretary Duncan? 
They were in Miami with ex-Governor Jeb Bush, celebrating the successful turnaround of Miami Central High School, where the entire staff had been replaced. The journalists dutifully reported the happy story. A wonderful, heart-warming, human interest story. But it wasn't true. A month after the ceremonies, the state department of education in Florida informed Miami Central High School that it was on the list to be closed because of persistent low performance. No one in the media followed up. They had been hoaxed.

Consider the debate about teacher quality, which is a crucial element in the Race to the Top program. Those who call themselves reformers say that the teacher is the most important determinant of student test scores, even though the overwhelming majority of researchers agree that the influence of family dwarfs the influence of teachers. Teachers are very important to students' learning, but families are even more important in providing a home, food, values, attitudes, and security.

Because the fake reformers believe that teachers are determinative of student test scores, they place high value on finding great teachers and rewarding them and on finding bad teachers and firing them. The reformers became convincedmostly by economists - that test scores are the measure that works best to identify the best and the worst teachers. So now we have federal policy and state policy that treat student scores as the most important indicator to determine who should get a bonus and who should be fired.

The Gates Foundation led the way on this initiative. It awarded districts hundreds of millions of dollars to implement value-added measures. After five years of trying, there is no evidence that this method works. The main thing it does is to demoralize teachers, because they know that they are being judged by factors beyond their control.

The American Educational Research Association (AERA) and the National Academy of Education wrote a joint paper and held briefings on Capitol Hill to warn legislators that value-added measurement was fraught with error and simplistic assumptions. They said it was inaccurate and unstable, that a teacher who was effective one year might be found ineffective the next year, because of the composition of his or her class. They said that student test scores were influenced by the school's resources, class sizes, curriculum, leadership, peer culture, by home and school supports and challenges, by the students' health and attendance, by the students' prior experiences and teachers, and by many other factors over which the teacher has no control. No matter. Just because the nation's most eminent researchers offer evidence is no reason for Congress to rein in the Department of Education from its baseless policies.

So now we have states like Florida, Colorado, and others tying 50 percent of teachers' evaluation to the test scores of their students. Some districts have fired the Teacher of the Year. Some states, like Florida, are evaluating teachers based on the scores of students they never taught. Some districts are developing tests for 
everything that is taught. Some states give tests not to judge the progress of the student, but to develop a rating for the teachers.

Behind these policies is the assumption by economists and statisticians that a child is like a bar of steel that can be bent and molded to shape, or like corn that will grow to a certain height if the farmer does everything right.

These are mechanistic assumptions that simply don't work well when the subjects are children, not corn or steel. Teachers know better. And teachers are deeply demoralized by policies that take away their professional autonomy and judge them by measures that are inherently unfair. Even the teachers with high ratings know that next year they might get a low rating through no fault of their own.

Some of our leading foundations and policymakers have decided that Teach for America is the answer to reaching that blessed day when all children have excellent schools. Forgive me if I am unable to explain how they reach that belief because I see no evidence for the idea that a group that recruits 10,000 new teachers a year, right out of college, and sends them to work in high-needs schools for two or three years, is a solution to anything other than a short-term vacancy.

Nonetheless, Teach for America says that its young recruits, with only five weeks of training, are superior to experienced teachers. Secretary Duncan believed them; he gave TFA \$50 million. The far-right Walton Family Foundation likes TFA and gave it more than $\$ 50$ million because its young teachers are crucial to the proliferation of nonunion charter schools. Just this week, we learned that the Walton Foundation gave TFA another \$20 million. Eli Broad, the Los Angeles billionaire, bundled $\$ 100$ million for TFA, because of their importance to the charter movement.

But despite the fact that TFA is a formidable fund-raising machine, its claims are not supported by independent researchers like Darling-Hammond, Barbara Torre Veltri, or Julian Vasquez Heilig and Su Jin Jez. TFA's most prominent alumni have stayed in education to become leaders of the privatization movement, like Michelle Rhee, who advocates for vouchers and charters and punitive policies toward teachers; or Kevin Huffman, state commissioner of Tennessee; or John White, state commissioner of Louisiana; or Erik Guckian, senior advisor to Governor Pat McCrory of North Carolina, whose hostile policies toward teachers have driven many veteran educators out of the state, while creating a new program for TFA. All of these TFA alumni support not only charters but vouchers, even those that go to fundamentalist schools that teach creationism as science.

The underlying message of TFA is that teachers can be great with only five weeks of training. That certainly eviscerates any need for professional preparation. What kind of a profession could call itself a profession based on only five weeks of training?

The latest innovation of the reformers is the creation of "graduate schools" to train charter teachers. These graduate schools have no scholars or researchers. 
They have no doctorates. They don't teach child development or foundations of education. They teach techniques for classroom management, data analysis, and how to raise test scores. Secretary Duncan recently visited the Match Graduate School of Education to show his approval of this new approach. If you believe that a full education consists of nothing more than scores on standardized tests, then I suppose this makes sense. If you think that professional educators should be prepared as professionals, if you believe that there is a research component to the study of education, then it is an insult to the profession.

The latest salvo against professional education came from a group called the National Council for Teacher Quality, or NCTQ. I was there at the creation, when NCTQ was funded by the Thomas B. Fordham Foundation in 2000. Its mission was to harass education schools and encourage the creation of alternative paths into teaching. For a while, it floundered, not sure how to go about this herculean task, but just before it ran out of money it was rescued by Secretary of Education Rod Paige, who gave NCTQ a grant of $\$ 5$ million to sustain it.

Fast forward to the present. NCTQ is now treated by the media as a reputable source on judging the quality of education schools and teacher evaluation, although it is not an accrediting body and not a research organization. NCTQ recently released a report that rated 1,300 colleges and universities of education; it was published by US News \& World Report. NCTQ described the teacher education sector as "an industry of mediocrity." It found that only four institutions in the entire nation were worthy of its highest rating: four gold stars. The rest ranged from bad to "consumer beware." How did it make these sweeping judgments? Not by visiting campuses, not by interviewing faculty, but by reading course catalogues and syllabi. The more an institution mentioned the words "Common Core" and phonics, the higher its rating.

Now, I ask you, would you take seriously an evaluation of a university program that did not involve any site visits? The NCTQ report was akin to reviewing restaurants based on their menus, not tasting their meals.

Yet the media treated the NCTQ report as an important and meaningful analysis of teacher education. To make matters even more confusing, NCTQ said that first-year teachers were so woefully prepared that they actually did harm to their students. And in the next breath, it praised TFA and the New Teacher Project, which send out first-year teachers, presumably to do harm, for having high entry standards.

But evidence doesn't matter.

Over the past dozen years, American education has been subject to continual disruption bordering on chaos. Well-funded groups are attacking teachers' rights to due process, even their pensions. Right now in Los Angeles, a Silicon Valley entrepreneur has bankrolled a lawsuit claiming that teacher tenure denies the civil rights of minority students. A billionaire in Texas is underwriting reports and 


\section{Diane Ravitch}

media campaigns claiming that public-sector pensions are bankrupting the nation. In North Carolina, a billionaire libertarian is the state budget director, leading the charge against teachers and public education.

I don't know of any evidence that due process rights for teachers hurts student achievement. The lead plaintiff in the case is a child named Vergara, and her teacher Antony Mize testified. He has an unblemished record, and he does not have tenure. If he harmed her education, why wasn't he fired? One might also point out that students in districts with high test scores have due process rights, but what's evidence got to do with an ideological campaign to strip teachers of their job protections, their right to a fair hearing, and their pensions?

Meanwhile, in state after state, for-profit charter schools are raking in millions of dollars, taking advantage of federal tax credits, and paying themselves outrageous rental fees. One such for-profit corporation in southern Florida has created a real estate empire of more than $\$ 100$ million, built with public school dollars; a member of the family that owns this business is in the legislature, chair of the education appropriations committee. It is a good business. Michael Milken, the junk bond king, runs the nation's largest virtual charter school chain. In Michigan, more than 80 percent of the charters operate for profit. Ohio spends $\$ 1$ billion a year on charters, which perform worse than public schools, and escape accountability because their owners give handsome campaign contributions to important elected officials. Athletes and rappers are opening for-profit charter schools. Some of them are high school dropouts. Why are they allowed to open schools and collect tuition? Taxpayers complain of the high cost of education, but which policymakers are trying to bring accountability and integrity to the for-profit charter industry?

My nominee for the most egregious waste of public funding is the virtual charter industry. These are online charter schools like K12 that advertise heavily, recruit constantly, and collect full state tuition for every student they enroll. Essentially, the students are home-schooled, and the corporation makes a large profit. These virtual charters have a high annual dropout rate, low test scores, and low graduation rates. I have been told by those who have reviewed their tests that they are a joke. Students often skip the instructional materials and go straight to the tests because the questions are so simple.

I won't go on with the catalogue of horrors associated with high-stakes testing, the charter industry, the voucher industry, the junk science embedded in current teacher evaluations, nor their academic apologists.

I want to make two points.

At issue is the future of American public education. How long can our policymakers continue on their present path of doling out public dollars to entrepreneurs and amateurs?

At issue is the future of the teaching profession. If we continue on the present course of demeaning and disrespecting teachers, awarding big contracts to 
amateurs while burdening veterans with mountains of paperwork and holding them accountable for social conditions they did not create and cannot change, who will want to be a teacher?

You might have gotten the impression from my talk thus far that evidence doesn't matter. Right now, I would have to say that is correct. Our policymakers continue to promote policies that harm children and ruin education.

I think they can be stopped. If I didn't think so, I wouldn't be here.

I think they can be stopped by evidence.

I strongly believe that everything these so-called reformers have put in place at the federal level and in the states is failing or has already failed. They like to point to New Orleans as the success story of our time, because a natural disaster wiped out public education and destroyed the teachers' union. Now 80 percent of the students in New Orleans are in privately managed charter schools staffed by nonunion TFA, who stay for two or three years and leave. This is supposed to be a wonderful thing. But what the reformers won't admit is that the majority of charter schools have been rated D or F by the state. Even the Cowen Institute at Tulane, a strong supporter of the charters, says that two-thirds are poor schools. This is not a model for the transformation of American education.

Bear in mind that none of the high-performing nations of the world have charters or vouchers. They have equitable public school systems staffed by highly professional teachers and respected by the community. They recognize that public education is a public responsibility, not a civic good.

I believe that we have an obligation to document what we know, to present the evidence in scholarly journals and in popular forums. We must do our work, connect it to public policy, and inform the public about what improves teaching and learning. We must devise better ways of judging school quality and teacher quality than standardized tests. We must document again the importance of family and community in the lives of children. We must demonstrate again how school and society interact. I find it useful to point out that few or none of the reformers put their own children into schools that follow their recommendations. They don't want their children in no-excuses charter schools. They don't want their children in schools that devote weeks to test prep. Like Bill Gates and Barack Obama, they want schools that have small classes and experienced teachers; they want a curriculum that emphasizes the arts and creativity; they want the best technology; they want a school that has the resources it needs for the students it enrolls.

Today we need researchers willing to engage in the public debate. There are many who do this, and they deserve our gratitude. David Berliner and Gene Glass have been tireless in support of sound research and in support of public education and the noble profession of teaching; their recent and timely book, 50 Myths and Lies That Threaten America's Public Schools, came at the right time. Julian Vasquez Heilig's blog Cloaking Inequity is a valuable research-based resource for those who 


\section{Diane Ravitch}

believe that all children deserve equity, not hollow promises. Bruce Baker of Rutgers has emerged as our premier research warrior, debunking nonsense no matter what its source. Linda Darling-Hammond has provided invaluable scholarship and vision about the needs of children, teachers, and schools today. Kevin Welner at the University of Colorado has gathered a stable of excellent researchers connected to his National Education Policy Center who frequently fact-check the latest claims by think tanks and bunkum artists. Stephen Krashen has been a voice of reason in public debates. Christopher and Sarah Lubienski patiently explained The Public School Advantage in their book of that name. Tim Slekar, dean of Edgewood College in Madison, has made videos, created a blog and podcasts, all with the intention of informing the public. Richard Rothstein has repeatedly documented the importance of poverty and class in school performance, a lesson that has been lost on our current policymakers. David Kirp has demonstrated in his work Improbable Scholars that public schools can turn themselves around without disrupting the lives of adults and children. Edward Haertel and Audrey Amrein-Beardsley have assembled the research showing that value-added measurement (VAM) is a sham. In 2014, the American Statistical Association warned against using test scores to rate individual teachers. Countless teachers have created their own blogs to explain in plain and moving language what is happening in their schools and the misdirection of the current status quo policies of the Bush-Obama era.

Not only scholars, but superintendents like John Kuhn of Texas, principals like Carol Burris of Rockville Center, New York, and teachers like Anthony Cody of Oakland, Katie Osgood of Chicago, and Jose Vilson of New York City have worked to inform the public. I can't name them all, and I hate to overlook anyone.

It is crucial that we continue to do our work, do it with integrity, and find ways to communicate our findings to the public.

The test-measure-and-punish policies of the Bush-Obama era are harmful to the public school system that is one of the most essential institutions of a democratic society. Those policies encourage not only privately managed charters, for-profit charters, but vouchers as well, which violate the traditional separation of church and state and enable children to take public tuition to schools with uncertified teachers where creationism is taught as science.

It is not credible that the path to improvement of education is to turn public dollars and children over to corporations, whether they operate for profit or not for profit, because it is in their interest to cut costs by having low-wage workers, high turnover of teachers, and large classes.

It is unreasonable to believe that teaching and administration should be relinquished to amateurs.

None of this makes any sense.

Policymakers at the federal and state level have ignored evidence in shaping NCLB and RTTT. It is our job to put the evidence before them again and again, 
until they can't ignore it anymore. Nothing they are doing now actually improves education. Nothing they are doing now will reduce poverty and segregation, which are the root causes of low academic performance. The status quo is hurting children and undermining education.

Each of us, in whatever work we do, must write in accessible prose. Each of us, I hope, will join in the work of reclaiming education and improving the lives of children, families, and communities. Each of us, I hope, will work, individually and together, to bring about the day when evidence does matter-to legislators and policymakers.

And so I call upon you to join in the most important issue of our time. Lend your knowledge and expertise to the local save-our-schools parent groups. Help the teachers who are in desperate need of your moral support. Join the Network for Public Education. Join the blogosphere. Enter the arena. Put your shoulder to the wheel or put your hands on your computer and join the resistance against the status quo. Join the battle to provide a good and equitable education for all children.

John Dewey said it best: "What the best and wisest parent wants for his own child, that must the community want for all of its children; anything less is unlovely. Acted upon, it destroys our democracy."

And that, my friends, must be our mission.

Diane Ravitch is Research Professor in the Humanities and Social Sciences in the Steinhardt School of Culture, Education and Human Development at New York University. Email: gardendr@gmail.com. 
